sources of information, the statement of the results for all countries, details as to the method of investigation, and so on, but the condensed tabular summary which follows is typical of the results as a whole :-

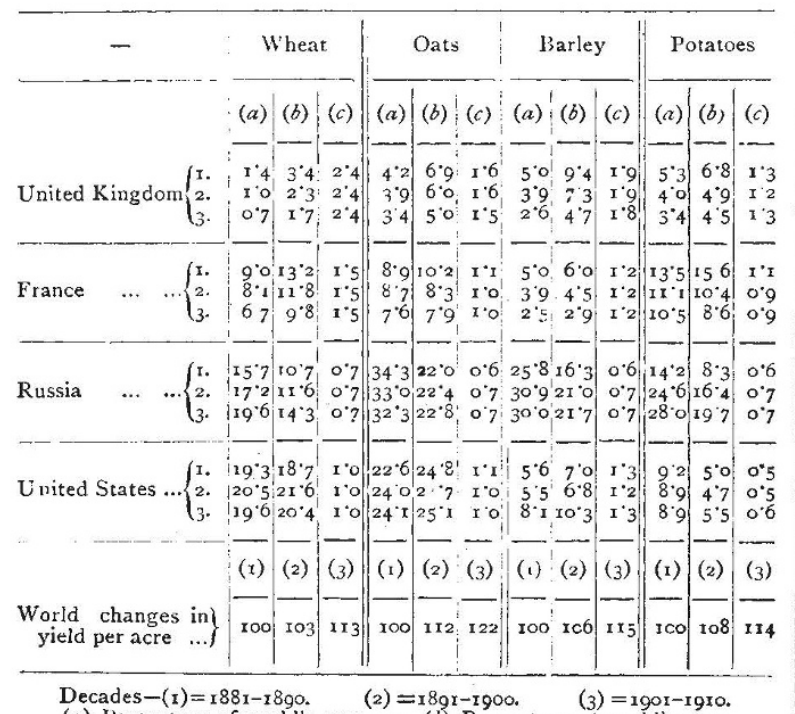

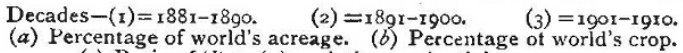

(c) Ratio of $(b)$ to $(a)=$ relative productivity per acre.

Column (a) gives the average percentage acreage for the three last decades, and column (b) the average percentage total crop; France is typical of the countries which have declined, and Russia of those which have improved under these heads. Column $(c)$ measures relative productivity, which has been practically constant all the world over for the three decades. Information is added to show the increases which have taken place for the world as a whole in relative yield per acre.

The end of the nineteenth century may be considered as the close of a commercial revolution due to improved communications and transport, \&c., and therefore the period under review is notably distinct from earlier epochs, so that the relative constancy of the productivity of these and other crops may be held to be a characteristic of this revolutionary period. Farming is a world business; improved results are common to all countries. The figures are instructive with reference to the threat of a world famine, e.g. if Russia only improved to the level of the United States, there would be an increase of 6 per cent. in the world's crop of wheat. At the same time it becomes obvious that the British farmer is the most successful farmer in the world; he always obtains a higher yield for each acre of land he tills. These are but the most important conclusions to which these results point; others may suggest themselves to your readers.

Granville Road, North Finchley, N.

\section{The Elephant Trench at Dewlish-Was it Dug?}

I was not aware that it had occurred to $\mathrm{Mr}$. Clement Reid, before it had done so to me, whether the Elephant Trench might have been excavated by man. $\mathrm{He}$ does not refer to this in his survey memoir on the Dorchester district; and so far as I can recollect he did not mention it when I described the trench with lantern slides at the meeting of the British Association at Cambridge in 1904. He now states NO. 2293, VOL. 92$]$
(Nature, Sept. 25) that he is convinced that the trench was due to natural agencies, and suggests that it was "probably wind-cut by the swirl of the fine dust-like quartz sand which, mixed with polished flints, now fills the lower part."

For my part I cannot imagine how such a trench could have been formed in that manner. He says that he found the sides of the trench "curiously smooth, and no tool marks nor rubbings such as might be made by man working in the trench, or by wild beasts," and also that the flint nodules projected into the cavity from either side as though the softer chalk had been scoured away. The fine sand which partially fills the trench is, I think, to all appearances wind-borne; and during the long interval which probably elapsed before the trench had become filled up by natural agencies the surface of its walls would have become weathered away, and possibly abraded by the sand, leaving the courses of flints projecting, and completely obliterating any tool marlis.

Mr. Reid remarks : "If this sand-filled fissure is found to continue downwards, but is too narrow for a man to work in, it will show that the trench is not artificial." On the other hand, my late lamented friend the Rev. R. Ashington Bullen wrote to the Geological Magazine (July, I910, p. 334), describing a pitfall to catch antelopes. It was io $\mathrm{ft}$. deep, $2 \mathrm{ft}$. wide at the top, narrowing at the bottom to a fere inches.

I may, however, say that when I dug at the end of the trench on the hill-face I came to the conclusion that the bottom of the trench was a flat chalk surface, and near the bottom I found some angular coarse gravel, and among it a nearly worn-down molar along with the polished flints. If, as Mr. Reid suggests, the trench was excavated by wind, which appears to me impossible, all the flints corresponding to the chalk so removed ought to lie, now, unbroken at the bottom, but in my notebook I find the remark that the flints in this gravel did not appear to have come "from the chalk direct."

I am extremely glad that Mr. Reid's interesting reply to my letter shows that I have succeeded in directing the attention of geologists to this, as I believe, important question.

Graveley, Huntingdon, September 26.

O. Fisher.

Referring to Mr. Clement Reid's letter on the origin of the Elephant Trench at Dewlish, in Nature of September 25, on the Yorkshire wolds holes are not infrequently scooped out of the chalk by what are locally termed "cloudbursts." One such, I3 ft. deep, occurred in the parish of South Cave last year.

I5 Bowlalley Lane, Hull, October 4.

G. W. B. MACTURK.

\section{A New Poet of Nature.}

READERS of The English Revieze must be inured to shocks; but among the revolutionary visions which its young men have seen, surely nothing more startling has been recorded than this, which I extract from a short poem entitled "Early One Morning":-

"Have you heard what the young moon said to me

As I walked in the morning early?

She lay on her back and laughed at me

As I walked in the morning early."

W. D. E. 